\title{
Detection of Citrus Huanglongbing-Associated 'Candidatus Liberibacter asiaticus' in Citrus and Diaphorina citri in Pakistan, Seasonal Variability, and Implications for Disease Management
}

\author{
Muhammad F. Razi, Manjunath L. Keremane, Chandrika Ramadugu, Mikeal Roose, Iqrar A. Khan, and Richard F. Lee
}

First and fifth authors: University of Agriculture, Faisalabad, Pakistan; second and sixth authors: United States Department of AgricultureAgricultural Research Service, National Clonal Germplasm Repository for Citrus and Dates, Riverside, CA 92507; and third and fourth authors: Department of Botany and Plant Sciences, University of California, Riverside 92507.

Accepted for publication 2 October 2013.

\begin{abstract}
Razi, M. F., Keremane, M. L., Ramadugu, C., Roose, M., Khan, I. A., and Lee, R. F. 2014. Detection of citrus huanglongbing-associated 'Candidatus Liberibacter asiaticus' in citrus and Diaphorina citri in Pakistan, seasonal variability, and implications for disease management. Phytopathology 104:257-268.
\end{abstract}

ABSTRACT

We report the detection of the huanglongbing (HLB)-associated bacterium 'Candidatus Liberibacter asiaticus' from both plants and insects in Pakistan and the seasonal variability in the numbers of ' $\mathrm{Ca}$. L. asiaticus'positive psyllid vector, Diaphorina citri. Our studies showed that ' $\mathrm{Ca}$. L. asiaticus' was detectable from trees in areas with maximum temperatures reaching nearly $50^{\circ} \mathrm{C}$ (average maximum of $42^{\circ} \mathrm{C}$ ). However, the bacterium was present at very low levels in psyllids both in summer (June to August) and autumn (September to November) in contrast to reports from
Florida, where the bacterium was detectable at very high levels during October to November. We hypothesize that hot summer temperatures in Pakistan may interfere with acquisition and replication of ' $\mathrm{Ca}$. L. asiaticus' in psyllids and may lead to dead or nontransmissible ' $\mathrm{Ca}$. L. asiaticus' in plants. Psyllid counts were very low in both summer and winter, showed a population peak (' $\mathrm{Ca}$. L. asiaticus'-positive vectors) in spring, and showed a larger peak (' $\mathrm{Ca}$. L . asiaticus'-free psyllids) in autumn. Natural thermotherapy during hot summers and a low vector population during environmental extremes may have played a major role in longterm survival of the citrus industry in Pakistan. These results may be useful in developing management strategies for U.S. citrus industries in Texas and California.

Additional keywords: seasonal variation.
Huanglongbing (HLB) is the most destructive disease of citrus worldwide (12) and is known to be putatively associated with three putative species of phloem-limited $\alpha$-proteobacteria ('Candidatus Liberibacter asiaticus', ' $\mathrm{Ca}$. L. africanus', and ' $\mathrm{Ca}$. L. americanus') (39,54), of which ' $\mathrm{Ca}$. L. asiaticus' is prevalent in Asia and the Americas. The disease is transmitted mainly by two psyllid species, Diaphorina citri Kuwayama (Hemiptera: Sternorryncha: Liviidae) and Trioza erytreae (del Guercio) (Hemiptera: Sternorryncha: Triozidae); D. citri is the main vector in Asia and the Americas $(14,21,27,29,49)$. Recently, two additional psyllid vectors, Cacopsylla citrisuga (Hemiptera: Psyllideae) and D. communis Mathur (Hemiptera: Sternorryncha: Liviidae), have been reported as vectors for ' $\mathrm{Ca}$. L. asiaticus' $(15,22)$. Although the HLB-associated Liberibacters have not been cultured in pure form and Koch's postulates have not been fulfilled, repeated association of Liberibacters with diseased plants has led to the assumption that Liberibacters are causal agents of HLB in citrus $(12,16)$.

Citrus is an important fruit crop in Pakistan, cultivated on $\approx 200,000$ ha with production estimated to be $\approx 2.3$ million metric tons (t) (6). Pakistan is ranked 13th in the world in citrus production, with $\approx 96 \%$ of the total citrus production in the Punjab

Corresponding author: R. Lee; E-mail address: richard.lee@ars.usda.gov

* The $\boldsymbol{e}$-Xtra logo stands for "electronic extra" and indicates that the online version contains one supplemental figure. Figure 7 appears in color online.

http://dx.doi.org/10.1094/PHYTO-08-13-0224-R

This article is in the public domain and not copyrightable. It may be freely reprinted with customary crediting of the source. The American Phytopathological Society, 2014 province (6). About $\approx 80 \%$ of the cultivated citrus is 'Kinnow' mandarin (Citrus reticulata Blanco), grown mainly in Sargodha and its surrounding areas, including the districts of Toba Tek Singh, Faisalabad, and Sahiwal (41). 'Kinnow' and 'Fewtrell's Early' mandarin were imported to the Indian subcontinent in 1940 from California and Australia, respectively, and acclimatized well in Punjab (5). Rough lemon (Citrus $\times$ taitensis Risso $(=\times$ jambhiri Lush.)) and sour orange (Citrus $\times$ aurantium L.) are the most common rootstocks. The average yield of citrus fruit in Pakistan is low, $\approx 12 \mathrm{t} / \mathrm{ha}$, which is $\approx 40 \%$ of the yield reported in the United States (6).

Citrus dieback was a major problem in the Indian subcontinent (including India, Pakistan, and other countries situated on the Indian plate) dating back to the 18 th century $(7,13)$. During the early 1900 s, the disease, referred to as citrus decline in the Indian subcontinent was attributed to several biotic and abiotic factors. In 1909, D. citri (syn. Euphalerus citri (Kuwayama)) was reported to be present on citrus in India in considerable numbers $(19,20)$. Husain and Nath describe dieback and losses associated with D. citri infestations in orchards in Sargodha area in 1916 (38). Leaf mottling symptoms that are typical of HLB were also described from this region by Asana (7). A clear association between the psyllid and the disease was demonstrated by Capoor et al. (14) by psyllid transmission in India. The suspected presence of HLB in Pakistan and in neighboring India has been documented in several publications $(1-3,7,25,38)$, based mainly on visual symptoms. Although HLB has been known in Pakistan for many decades, adequate information is not available regarding the population dynamics of $D$. citri, appropriate times for effective psyllid control, or optimal time frame for testing psyllids or plants for the presence of HLB-associated bacteria. Chohan et al. (17) 
demonstrated the presence of HLB in citrus from the North-West Frontier Province of Pakistan (Khyber Pakhtunkhwa) by polymerase chain reaction (PCR) and sequencing of the rplKAJL$r p o B C$ region of the ' $\mathrm{Ca}$. L. asiaticus' genome. To our knowledge, this is the only report of molecular evidence of HLB-associated Liberibacters in Pakistan.

HLB has been a challenging disease from both crop management and research perspectives because of various factors, including the fastidious nature of the HLB-associated bacteria, irregular distribution, long latency in plants, seasonality, and lower incidence of the bacteria in psyllids $(26,47)$. In areas where the vectors are present but HLB has not been found, even the most sensitive diagnostic tests available are considered inadequate to certify the area as HLB-free (47). Once the disease is prevalent, management of HLB and maintenance of productive citrus groves is challenging. Good sources of genetic resistance to HLB in the genus Citrus or its relatives have not been identified $(4,27)$. Current attempts to manage HLB, practiced in most of the citrusgrowing regions of the world, involve continuous prevention of introduction on new plants by use of pathogen-free planting materials, monitoring of vectors, suppression of psyllid populations by application of systemic and contact insecticides in the groves, and timely removal of infected trees (26).

Epidemiological models of HLB spread were developed based on symptoms and assumed a linear relationship between infection and symptom expression because the actual timing of HLB infection cannot be determined $(21,26)$. Under greenhouse conditions, the incubation period from grafting to development of HLB symptoms is 3 to 12 months (46). However, for large trees in a field situation, the incubation period may be much longer, up to $\geq 5$ years $(47,52)$. The latent period for HLB, the interval between when a plant is infected by a psyllid and the time when that plant can serve as a source of spread by other psyllids, can vary.

The recent rapid spread of HLB in Brazil and Florida $(18,28$, 54) and its impact on these two major citrus industries in a short span of time has led to increased concern among growers, regulators, and researchers. An analysis of the situation in Pakistan may be useful in understanding the dynamics of citrus HLB in a situation where citrus, the psyllid vector, and the pathogen may have coexisted for more than a century. In Pakistan, the disease does not appear to be as severe as reported from southern Florida or the HLB-affected area of São Paulo State, Brazil. The longterm effects of HLB on the citrus industry in Pakistan seem to be different as compared with regions in the western hemisphere where HLB has been introduced recently. A detailed study of the pathosystem from Pakistan would also be of special interest to the United States because both the Punjab region of Pakistan and many citrus-growing regions of the United States have very similar agroclimatic conditions, though only the Punjab region has a monsoon season. Using a climate modeling program, CLIMEX, Hoddle has reported a $70 \%$ climate match between citrus production areas of California and the Punjab region of Pakistan (34).

The objectives of the present study were to (i) confirm the presence of the HLB-associated bacterium from both citrus and psyllids in Pakistan using molecular methods; (ii) conduct preliminary sequence analyses and determine whether the bacterium is similar to the strain of ' $\mathrm{Ca}$. L. asiaticus' reported from the United States; (iii) assess seasonal variation in psyllid populations, because such information may be useful in devising ways to mitigate psyllid populations by strategically timed spray schedules; and (4) develop information on the prevalence of ' $\mathrm{Ca}$. L. asiaticus' in psyllids during different seasons, which would be beneficial for disease management in Pakistan. The findings are also of interest to California, Texas, and Arizona, in the United States, where similar climates occur, the Asian citrus psyllid is becoming established, HLB-infected trees are being found, and there is a likelihood that HLB may prevail $(42,43)$.

\section{MATERIALS AND METHODS}

Population dynamics of $\boldsymbol{D}$. citri. The insect population study was carried out from April 2008 to March 2009. Surveys of $D$. citri populations were conducted in four tehsils (an administrative subdivision): Bhalwal, Kot Momen, Sargodha, and Sillanwali in Sargodha District (Fig. 1; regions marked 2, 3, 5, and 7, respectively). In total, 12 orchards were surveyed-3 for each tehsil. Monitoring of the populations was carried out using a split-plot experimental technique under a randomized complete block design. In each tehsil, three citrus orchards with a minimum orchard-to-orchard distance of $5 \mathrm{~km}$ were chosen for the study. Five trees were selected in each orchard in a diagonal pattern with a tree-to-tree distance of $\approx 50 \mathrm{~m}$. Five yellow sticky traps (10 by $15 \mathrm{~cm}$ ) were placed on each tree for monitoring the insect populations $(30,32)$. The yellow sticky traps were hung at $1.5-$ to $2-\mathrm{m}$ heights directly on the canopy of each tree; one trap was placed in each cardinal quadrant and the fifth was positioned in the center of the tree. The yellow sticky traps were replaced weekly, and the number of psyllid adults in each trap was recorded. The data collected for 45 weeks was analyzed using SPSS (version 19.0; IBM, Armonk, NY). The tehsils, orchards, and tree quadrants (including the center of the tree) served as split plots, complete blocks, and treatments, respectively.

Collection of $\boldsymbol{D}$. citri samples. Live psyllids were collected using an aspirator from 43 orchards in 11 different citrus-growing regions of Sargodha District (Fig. 1). In total, 304 psyllid samples were collected from April 2009 to July 2010 from individual trees and stored in $95 \%$ ethanol at $-20^{\circ} \mathrm{C}$ at the Institute of Horticultural Sciences, University of Agriculture Faisalabad, and shipped to the United States Department of Agriculture-Agricultural Research Service (USDA-ARS), Riverside, CA for quantitative (q)PCR analysis. Each psyllid sample consisted of 2 to 350 adult psyllids collected from a single tree in a specific location. Most samples had $\approx 50$ psyllids. In total, 7,573 psyllids were analyzed in this study (Tables 1 to 3 ).

Collection of plant samples. Trees showing fruit color inversion, lopsidedness, yellow shoots, and upright branching pattern were selected for leaf sample collection. Fully expanded and hardened symptomatic leaves with asymmetric leaf mottle were collected from trees of four varieties of citrus (Kinnow mandarin, Fewtrell's Early mandarin, 'Mosambi' sweet orange $[C$. sinensis (L.) Osbeck], and grapefruit [C .paradisi Macfad.]) obtained from 43 orchards in eight citrus-growing areas (Fig. 1). For each tree sampled, at least 50 symptomatic leaves were collected, wrapped in aluminum foil, labeled, and transferred to a cool box containing dry ice and later stored at $-80^{\circ} \mathrm{C}$ at the Institute of Horticultural Sciences, University of Agriculture, Faisalabad, until used for DNA extraction. In total, 207 plant samples were collected from eight regions during spring (March to May) and summer (June to August).

DNA extraction from psyllids. In total, $\approx 2,321$ psyllid DNA extractions were prepared using multiple (up to five) psyllid nymphs or adults. MagAttract 96 DNA plant core kit (Qiagen Inc., Valencia, CA) was used for insect DNA extraction according to the manufacturer's protocol, with some modifications. Briefly, the psyllids were air dried for $10 \mathrm{~min}$ and transferred to a 1-ml, 96-deep-well, round-bottom microplate, with each well containing 10 zirconium beads of $2.5 \mathrm{~mm}$ in diameter. After adding RLT (Qiagen) extraction buffer $(300 \mu \mathrm{l} /$ well), the plate was covered using capcluster mat (USA Scientific) and homogenized twice for 3 min using a Mini beadbeater (Biospec, Ocala, FL). The microplate was then processed using the MagAttract protocol, as suggested by the manufacturer. The final DNA eluates $(100 \mu \mathrm{l}$ each) were transferred to a new 96-well round-bottom microplate which was sealed, labeled, and stored at $-20^{\circ} \mathrm{C}$ until further use. To calculate the exact percentage of ' $\mathrm{Ca}$. L. asiaticus'positive psyllids from different regions and collected at different 
time periods, an additional 1,357 psyllids were also tested individually ( 1 psyllid per extraction) using the method described above.

Plant DNA extraction. Leaf petiole tissue $(\approx 0.5 \mathrm{~g})$ was extracted using cetyltrimethylammonium bromide (CTAB) in a laboratory located in Pakistan, as previously described (23). Briefly, finely chopped petiole tissue was pulverized in liquid nitrogen using a mortar and pestle, added to $5 \mathrm{ml}$ of hot $\left(65^{\circ} \mathrm{C}\right)$ CTAB reagent (containing 2\% [wt/vol] CTAB, $1.4 \mathrm{M} \mathrm{NaCl}$, $20 \mathrm{mM}$ EDTA, and $100 \mathrm{mM}$ Tris $\mathrm{HCl}, \mathrm{pH} 8.0$, with $1 \%$ polyvinyl pyrrolidone), and emulsified. The emulsion was added to an equal volume of chloroform/isoamyl alcohol (24:1), mixed well, incubated at $65^{\circ} \mathrm{C}$ for $30 \mathrm{~min}$, followed by centrifugation and ethanol precipitation. The DNA extracts were stored at $-20^{\circ} \mathrm{C}$ and shipped in ethanol to USDA-ARS, Riverside, CA for molecular studies.
At the USDA-ARS lab, the DNA was pelleted, washed with cold $70 \%$ ethanol, air dried, and resuspended in $200 \mu \mathrm{l}$ of $1 \times$ TrisEDTA buffer, $\mathrm{pH} 8$, and used for molecular analyses.

Multiplex real-time qPCR. A TaqMan-based real-time qPCR assay was used for detection of ' $\mathrm{Ca}$. L. asiaticus' in DNA extracts from psyllids (47). The quality of the DNA in the sample was evaluated by amplification of a fragment of the psyllid gene, Wingless. For DNA extracts from plants, a TaqMan-based realtime qPCR assay for amplification of a $16 \mathrm{~S}$ ribosomal (r)DNA fragment of ' $\mathrm{Ca}$. L. asiaticus' was conducted (45). The mitochondrial gene cytochrome oxidase was used as an internal control. The qPCR assays were performed using a Stratagene Mx3005P qPCR machine and cycle threshold $(\mathrm{Ct})$ values were determined using the Stratagene software. Samples with a Ct value of $\leq 34$ for ' $\mathrm{Ca}$. L. asiaticus' were considered as positive for ' $\mathrm{Ca}$. L. asiati-

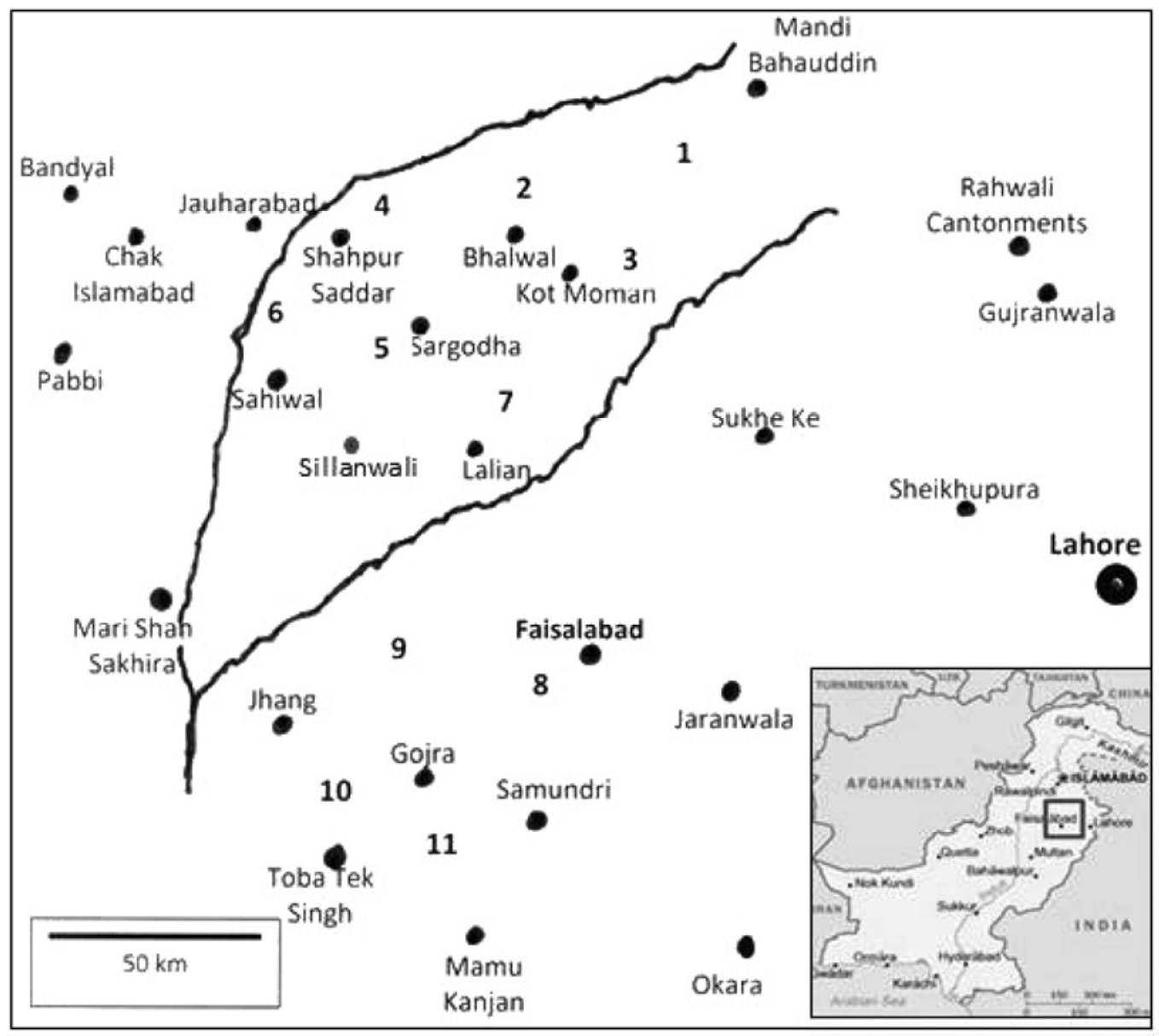

Fig. 1. Map showing citrus-growing regions of Sargodha District and surrounding regions in the Punjab Province of Pakistan where citrus orchards were selected for studies on population dynamics of Diaphorina citri and for analysis of psyllids and citrus for the presence of 'Candidatus Liberibacter asiaticus' associated with citrus huanglongbing disease. Regions targeted for the study were 1, Mandi Bahauddin; 2, Bhalwal; 3, Kot Momen; 4, Shahpur; 5, Sargodha; 6, Sillanwali; 7, Lalian; 8, Faisalabad; 9, Jhang/Shamsabad; 10, Gojra; and 11, Toba Tek Singh.

TABLE 1. Psyllid testing at different time points in four regions of Pakistan

\begin{tabular}{|c|c|c|c|c|c|c|c|}
\hline \multirow[b]{2}{*}{ Month of collection } & \multicolumn{3}{|c|}{ Samples } & \multicolumn{3}{|c|}{ Extractions $^{\mathrm{a}}$} & \multirow[b]{2}{*}{ Total psyllids analyzed } \\
\hline & $n$ & Positive $(n)^{\mathrm{b}}$ & Positive $(\%)$ & $n$ & Positive $(n)^{\mathrm{b}}$ & Positive (\%) & \\
\hline February & 13 & 11 & 85 & 72 & 14 & 19 & 202 \\
\hline March & 56 & 8 & 14 & 315 & 22 & 7 & 1,178 \\
\hline May & 36 & 16 & 44 & 507 & 88 & 17 & 913 \\
\hline June & 11 & 1 & 9 & 42 & 1 & 2 & 142 \\
\hline July & 43 & 3 & 7 & 139 & 3 & 6 & 532 \\
\hline
\end{tabular}

a Extractions were made from five psyllids.

b Number found positive for 'Candidatus Liberibacter asiaticus'. 
cus'. All qPCR reactions were run simultaneously, with many negative controls that consisted of sample extractions without psyllid or plant samples. Using rigorous controls, we feel confident that a $\mathrm{Ct}$ value of 34 can be considered as positive for ' $\mathrm{Ca}$. $\mathrm{L}$. asiaticus'.

Conventional PCR, cloning, and sequencing. Representative qPCR-positive plant and psyllid DNA extracts obtained from different regions of Pakistan (with $\mathrm{Ct}$ values $<27$ for the $16 \mathrm{~S}$ region) were used to amplify a $1.17-\mathrm{kb}$ region using $16 \mathrm{~S}$ rDNA primers OI1 and OI2c (40). The qPCR-positive plant samples were also used for PCR amplification of six other ' $\mathrm{Ca}$. L. asiaticus' genomic regions and the PCR products were cloned in pCR-4 TOPO (Life Technologies, Grand Island, NY). The clones were subjected to Sanger sequencing using vector-based primers. The genomic regions targeted were partial ABC transporter gene with a part of intergenic region, fumarate hydrase, FLP/FAP pilin com- ponent with intergenic region upstream of this gene, prophage antirepressor region along with part of a gene coding for a hypothetical protein, phage DNA polymerase, and ribonucleotide diphosphate reductase subunit $\beta$. The genes or regions targeted and primers used for the PCR amplification are listed in Table 4; the nucleotide numbering is based on the genomic sequence of 'Ca. L. asiaticus' (24). Sequences obtained were compared with ' $C a$. L. asiaticus' strain psy62 (24) and unique sequences were deposited in GenBank. Alignments of sequences were done using Clustal and GeneDoc programs $(50,55)$.

Weather information. For the Sargodha region of Pakistan, weather data for 2000 to 2012 were obtained from the District Agriculture office, Sargodha, and the Climate Data Processing Centre, Pakistan Meteorological Department, Karachi. For regions in the United States, similar data for 1982 to 2012 were accessed from http://www.almanac.com/weather/history.

TABLE 2. Detection of 'Candidatus Liberibacter asiaticus' in psyllids collected from eleven regions of Pakistan

\begin{tabular}{|c|c|c|c|c|c|c|c|}
\hline \multirow[b]{2}{*}{ Region } & \multicolumn{3}{|c|}{ Samples } & \multicolumn{3}{|c|}{ Extractions $^{\mathrm{a}}$} & \multirow[b]{2}{*}{ Total psyllids analyzed } \\
\hline & $n$ & Positive $(n)^{\mathrm{b}}$ & Positive (\%) & $n$ & Positive $(n)^{\mathrm{b}}$ & Positive (\%) & \\
\hline Bhalwal & 51 & 13 & 25 & 453 & 265 & 58 & 1,100 \\
\hline Faisalabad & 93 & 17 & 18 & 415 & 33 & 8 & 1,673 \\
\hline Gojra Talwandic $^{\mathrm{c}}$ & 5 & 0 & 0 & 20 & 0 & 0 & 106 \\
\hline Jhang, Shamasabad & 27 & 12 & 44 & 91 & 15 & 16 & 300 \\
\hline Kot Momen & 15 & 4 & 27 & 96 & 16 & 17 & 296 \\
\hline Lalian $^{\mathrm{c}}$ & 21 & 1 & 5 & 120 & 1 & 1 & 445 \\
\hline Mandi Bahauddin & 14 & 0 & 0 & 86 & 0 & 0 & 275 \\
\hline Sahiwal & 6 & 3 & 50 & 138 & 23 & 17 & 187 \\
\hline Sargodha & 32 & 3 & 9 & 124 & 4 & 3 & 455 \\
\hline Shahpur ${ }^{\mathrm{d}}$ & 11 & 1 & 9 & 42 & 1 & 2 & 142 \\
\hline Toba Tek Singh & 30 & 13 & 43 & 736 & 202 & 27 & 1,237 \\
\hline Total & 305 & 67 & 22 & 2,321 & 560 & 24 & 6,216 \\
\hline
\end{tabular}

a Extractions were conducted using mostly two to five psyllids per extraction.

b Number found positive for ' $\mathrm{Ca}$. L. asiaticus'.

c Collected during November, when percentage of ' $\mathrm{Ca}$. L. asiaticus'-positive psyllids is very low in Pakistan.

${ }^{\mathrm{d}}$ Collected in June, when percentage of ' $\mathrm{Ca}$. L. asiaticus'-positive psyllids is very low in Pakistan.

TABLE 3. Single psyllid extractions tested for the presence of 'Candidatus Liberibacter asiaticus'

\begin{tabular}{|c|c|c|c|c|c|}
\hline Extraction & Area & Date of collection & Psyllids tested $(n)$ & Positive $(n)^{\mathrm{a}}$ & Positive $(\%)$ \\
\hline 1 & Jhang, Shamsabad & 11 February 2010 & 7 & 0 & 0 \\
\hline 2 & Jhang, Shamsabad & 11 February 2010 & 7 & 1 & 14 \\
\hline 3 & Jhang, Shamsabad & 11 February 2010 & 8 & 1 & 13 \\
\hline 4 & Jhang, Shamsabad & 11 February 2010 & 9 & 0 & 0 \\
\hline 5 & Jhang, Shamsabad & 11 February 2010 & 9 & 1 & 11 \\
\hline 6 & Bhalwal & 5 March 2010 & 39 & 0 & 0 \\
\hline 7 & Bhalwal & 26 March 2010 & 4 & 3 & 75 \\
\hline 8 & Bhalwal & 26 March 2010 & 17 & 9 & 53 \\
\hline 9 & Mandi Bahauddin & 22 March 2010 & 40 & 0 & 0 \\
\hline 10 & Faisalabad & 16 April 2009 & 18 & 0 & 0 \\
\hline 11 & Faisalabad & 16 April 2009 & 22 & 1 & 5 \\
\hline 12 & Faisalabad & 16 April 2009 & 22 & 2 & 9 \\
\hline 13 & Faisalabad & 16 April 2009 & 22 & 2 & 9 \\
\hline 14 & Toba Tek Singh & 2 April 2010 & 69 & 29 & 42 \\
\hline 15 & Toba Tek Singh & 2 April 2010 & 82 & 43 & 52 \\
\hline 16 & Toba Tek Singh & 2 April 2010 & 131 & 22 & 17 \\
\hline 17 & Toba Tek Singh & 3 April 2010 & 34 & 22 & 65 \\
\hline 18 & Toba Tek Singh & 5 April 2010 & 108 & 48 & 44 \\
\hline 19 & Toba Tek Singh & 6 April 2010 & 187 & 4 & 2 \\
\hline 20 & Bhalwal & 7 May 2009 & 73 & 12 & 16 \\
\hline 21 & Bhalwal & 7 May 2009 & 78 & 10 & 13 \\
\hline 22 & Bhalwal & 7 May 2009 & 82 & 13 & 16 \\
\hline 23 & Kot Momen & 7 May 2009 & 48 & 10 & 21 \\
\hline 24 & Sahiwal & 7 May 2009 & 41 & 1 & 2 \\
\hline 25 & Sahiwal & 7 May 2009 & 87 & 19 & 22 \\
\hline 26 & Shahpur & 21 June 2010 & 18 & 0 & 0 \\
\hline 27 & Sargodha & 14 July 2010 & 41 & 0 & 0 \\
\hline 28 & Faisalabad & 6 November 2009 & 1 & 0 & 0 \\
\hline 29 & Faisalabad & 27 November 2009 & 13 & 0 & 0 \\
\hline 30 & Lalian & 21 November 2009 & 40 & 0 & 0 \\
\hline Total & $\ldots$ & $\ldots$ & 1,357 & 253 & 19 \\
\hline
\end{tabular}

a Number found positive for ' $\mathrm{Ca}$. L. asiaticus'. 


\section{RESULTS}

Population dynamics of $\boldsymbol{D}$. citri. Using yellow sticky traps placed at different quadrants of trees, we assessed insect populations in selected citrus orchards during April 2008 to March 2009 by recording numbers of adult psyllids. Cardinal trapping patterns remained unchanged among the different survey areas. Statistical analysis showed temporal and spatial variability in the mean number of adults trapped on yellow sticky cards. The highest recorded number of adults per trap per week was during November $(33.2 \pm 1.06)$ in the south quadrant of the tree and the lowest number was during December $(0.9 \pm 0.17)$ in the center of the tree (Table 5). Populations declined significantly during the winter months of January and February. In the summer months of June, July, and August, when the average maximum temperatures were 35 to $40^{\circ} \mathrm{C}$ (reaching a maximum of $52^{\circ} \mathrm{C}$ on certain days), more adults were collected from the traps placed in the center of the tree. During the first population peak period in spring (April to May), a higher number of psyllids were trapped in northern and central sectors of the tree compared with other tree quadrants but, during the second population peak period in autumn (October to November), the southern and western quadrants had higher numbers. During May (end of spring season), the highest mean number of adults were trapped in the northern quadrants $(14.4 \pm$ $1.93)$ and the center part of the trees $(12.4 \pm 1.51)$, a trend that prevailed until the end of summer (August). After September, the east, south, and west sides of the trees had significantly higher numbers of adults, and this pattern continued until onset of winter (December). During autumn (November), we recorded the highest trapping rate in the southern quadrant $(33.20 \pm 1.06)$ followed by the western $(28.80 \pm 1.0)$ and eastern $(27.90 \pm 0.98)$ quadrants (Fig. 2).

Psyllid population counts were recorded weekly from March 2008 to April 2009 from four regions in the citrus belt: Sillanwali, Sargodha, Bhalwal, and Kot Momen (Fig. 3A to D, corresponding to map regions $6,5,2$, and 3 in Figure 1). During the entire survey period, two distinct population peaks were observed (Fig. $3 \mathrm{~A}$ to $\mathrm{D}$ ); the first peak was during spring from mid-April to midMay and the second, larger peak was in autumn from mid-September to mid-November. The psyllid populations dwindled dur-

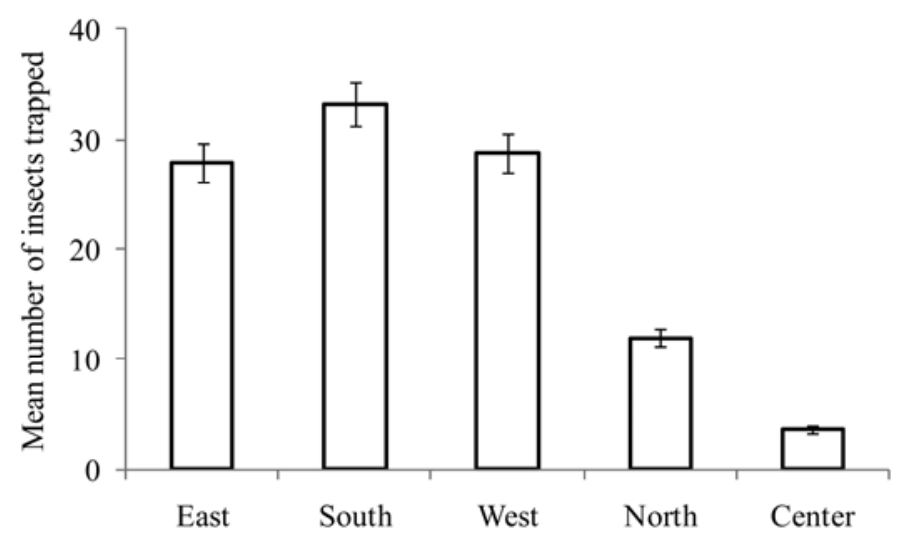

Fig. 2. Mean number of insects (Diaphorina citri) trapped on yellow sticky cards (per trap per week) placed at the four sides of the tree and in the center of the canopy in November 2009, when the psyllid population reached its highest level. Standard error bars are shown.

TABLE 4. Primers used to amplify genomic regions of 'Candidatus Liberibacter asiaticus' from positive plant and psyllid samples

\begin{tabular}{|c|c|c|c|c|c|}
\hline Primer number & Sequence & Position $^{\mathrm{a}}$ & Putative gene product & Reference & $\begin{array}{c}\text { GenBank accession } \\
\text { number (source) }\end{array}$ \\
\hline Cit 205 & GCGCGTATGCAATACGAGCGGCA & 418,261 & $16 \mathrm{~S}$ rRNA & 40 & $\begin{array}{l}\text { JQ866401 (psyllid) } \\
\text { JQ866408 (Citrus) }\end{array}$ \\
\hline Cit 206 & GCCTCGCGACTTCGCAACCCAT & 417,090 & $16 \mathrm{~S}$ rRNA & 40 & $\ldots$ \\
\hline Cit 700 & TGGAGTGATAAATTACCACG & 19,021 & $\mathrm{ABC}$ transporter protein & This study & JQ866402 (Citrus) \\
\hline Cit 701 & GCTACTTATTAGTCTGCGAA & 19,751 & $\begin{array}{l}\text { Intergenic region downstream of } \\
\mathrm{ABC} \text { transporter protein }\end{array}$ & This study & $\cdots$ \\
\hline Cit 702 & CTCTTGTTATCATACGTGCA & 76,291 & Fumarate hydrase & This study & JQ866403 (Citrus) \\
\hline Cit 703 & GCAACCCTGTAATGTCTC & 76,920 & Fumarate hydrase & This study & $\ldots$ \\
\hline Cit 706 & GCGGCTACTGAATATGT & 534,654 & $\begin{array}{l}\text { Intergenic region upstream of Flp/Fap } \\
\text { pilin component }\end{array}$ & This study & JQ866404 (Citrus) \\
\hline Cit 707 & GTGGTAACGGAAGTGAT & 535,322 & FLP/FAP pilin component & This study & $\ldots$ \\
\hline Cit 708 & GAGGTGTTACCTACTCTTCGC & 2,570 & Prophage antirepressor & 56 & $\begin{array}{l}\text { JQ866406 (Citrus) } \\
\text { JQ866405 (Citrus) }\end{array}$ \\
\hline Cit 709 & GTATCAAGAGCAGGGTACG & 3,140 & Hypothetical protein & 56 & $\ldots$ \\
\hline Cit 710 & CTCCGTATGACTGTACTCGTGC & 4,172 & Phage DNA polymerase & 56 & JQ866407 (Citrus) \\
\hline Cit 711 & CTTCACCAGCAATCCATGCC & 4,930 & Phage DNA polymerase & 56 & $\ldots$ \\
\hline B 21 & TGAAGCTAGCCAATAGCCATCCCA & 10,471 & Hypothetical protein & This study & JQ866409 (Citrus) \\
\hline B 26 & TTCGCTCATCCAAGGGAAAGGGTT & 11,466 & $\begin{array}{l}\text { Ribonucleotide-diphosphate reductase } \\
\text { subunit }\end{array}$ & This study & $\ldots$ \\
\hline
\end{tabular}

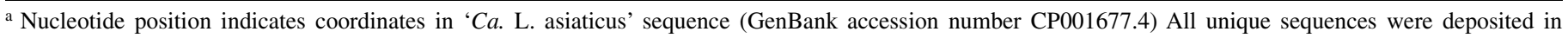
GenBank (last column).

TABLE 5. Mean number of adult psyllids trapped ( \pm standard error) on yellow sticky cards placed at different quadrants in the trees

\begin{tabular}{|c|c|c|c|c|c|}
\hline Sampling months & East & South & West & North & Center \\
\hline April & $10.05 \pm 1.43$ & $9.95 \pm 1.36$ & $10.40 \pm 1.37$ & $11.31 \pm 1.61$ & $8.22 \pm 1.06$ \\
\hline May & $8.55 \pm 1.38$ & $9.71 \pm 1.52$ & $9.37 \pm 1.41$ & $14.38 \pm 1.93$ & $12.44 \pm 1.51$ \\
\hline June & $0.74 \pm 0.095$ & $1.06 \pm 0.15$ & $1.23 \pm 0.14$ & $1.68 \pm 0.21$ & $3.58 \pm 0.42$ \\
\hline July & $1.12 \pm 0.13$ & $0.72 \pm 0.10$ & $0.81 \pm 0.086$ & $1.50 \pm 0.14$ & $2.23 \pm 0.21$ \\
\hline August & $0.59 \pm 0.05$ & $0.03 \pm 0.04$ & $0.21 \pm 0.03$ & $0.85 \pm 0.096$ & $0.70 \pm 0.071$ \\
\hline September & $4.28 \pm 0.22$ & $2.67 \pm 0.16$ & $2.30 \pm 0.15$ & $3.17 \pm 0.17$ & $1.99 \pm 0.11$ \\
\hline October & $23.66 \pm 1.00$ & $21.36 \pm 0.95$ & $21.70 \pm 0.97$ & $16.10 \pm 0.64$ & $7.43 \pm 0.25$ \\
\hline November & $27.85 \pm 0.98$ & $33.18 \pm 1.06$ & $28.84 \pm 1.00$ & $12.02 \pm 0.55$ & $3.65 \pm 0.19$ \\
\hline December & $5.32 \pm 0.46$ & $6.61 \pm 0.53$ & $5.04 \pm 0.43$ & $1.73 \pm 0.15$ & $0.88 \pm 0.17$ \\
\hline January & $0.00 \pm 0.00$ & $0.00 \pm 0.00$ & $0.00 \pm 0.00$ & $0.00 \pm 0.00$ & $0.00 \pm 0.00$ \\
\hline February & $0.00 \pm 0.00$ & $0.00 \pm 0.00$ & $0.00 \pm 0.00$ & $0.00 \pm 0.00$ & $0.00 \pm 0.00$ \\
\hline March & $2.89 \pm 0.17$ & $2.85 \pm 0.18$ & $2.68 \pm 0.17$ & $1.50 \pm 0.10$ & $0.95 \pm 0.08$ \\
\hline
\end{tabular}


ing two periods: one was in winter, during January to February, and the second lean period was during the hot summer months of June to August (average $=0$ to 4 psyllids /trap) (Table 5), coinciding with the peak monsoon season, with $\approx 68,96$, and 149 $\mathrm{mm}$ of rainfall in June, July, and August 2008, respectively. Data analysis of weather patterns for 12 years shows a similar trend (Fig. 4).

Psyllid population studies started by the end of March 2008, 3 weeks after the start of the spring flush, when conditions were ideal for insect proliferation; mild temperatures, low rainfall, and $\approx 80 \%$ relative humidity (data not shown) (Fig. 4A and 4B correspond to 12-year averages). During the last week of February (late winter) and first week of March (early spring), light to medium showers (resulting in tender flush) and warmer night temperatures of $\approx 15^{\circ} \mathrm{C}$ were observed and an increase of psyllid populations was recorded by the end of March (Fig. 3A to D). During the population peak in April (mid-spring), for the period of this study, the average rainfall was $88 \mathrm{~mm}$, average relative humidity was $\approx 73 \%$ (range 44 to $95 \%$ ), average maximum temperature was $33^{\circ} \mathrm{C}$ (maximum $42^{\circ} \mathrm{C}$ ), and average minimum temperature was $19^{\circ} \mathrm{C}$ (minimum $14^{\circ} \mathrm{C}$ ). The number of adult psyllids trapped on yellow sticky traps increased and peaked by the first week of May (Fig. 3A to C). Toward the end of May (with the onset of summer), the average maximum temperatures reached $39^{\circ} \mathrm{C}$ (range: 29 to $46^{\circ} \mathrm{C}$ ). A low trapping rate was recorded during July and August (summer), after the onset of the monsoon season in June. Rainfall and relative humidity information for the Sargodha region of Punjab province is shown in Figure 4B. Citrus plants are irrigated in Pakistan and produce flushes throughout the year, except in the winter (December to middle of February). The two major flushing periods were in spring (March to middle of May) and autumn (September to November). Very little flushing was observed during summer months.

There was a second period of rapid increase in D. citri populations from mid-September to mid-November (autumn), after the cessation of the summer monsoon and return of milder temperatures. During the second population peak period of October to November (Fig. 3), for the specific period of this study (April 2008 to March 2009), the maximum daily temperatures averaged $32^{\circ} \mathrm{C}$ (range: 24 to $39^{\circ} \mathrm{C}$ ) and minimum daily temperatures averaged $18^{\circ} \mathrm{C}$ (range: 9 to $26^{\circ} \mathrm{C}$ ). Rainfall was low in October $(3$ to $11 \mathrm{~mm}$ ) and very low in November (0 to $0.7 \mathrm{~mm}$ ), with average relative humidity of 79 to $86 \%$ (49 to $95 \%$ for brief intervals). During the second larger population peak in autumn, the low rainfall, moderate temperatures, and high relative humidity supported a large population increase. There was a steep decline in the number of adults trapped by the end of November, dropping to the lowest recorded level by late December, when tender flush was not available and minimum temperatures are closer to $0^{\circ} \mathrm{C}$. Either very few or no adult psyllids were observed on yellow sticky traps from the last week of December to the end of February, when new spring flushes started to emerge. During January, the average rainfall was $14 \mathrm{~mm}$, relative humidity was $\approx 90 \%$ (range: 81 to $94 \%$ ), average maximum temperature was $22^{\circ} \mathrm{C}$ (maximum $30^{\circ} \mathrm{C}$ ), and average minimum temperature was $8^{\circ} \mathrm{C}$ (minimum $5^{\circ} \mathrm{C}$ ). The meteorological data described in this section is for the period when population studies were conducted (April 2008 to March 2009). The average rainfall, relative humidity, and maximum and minimum temperatures recorded for 12 years are shown in Figure 4.

Among different regions surveyed, the highest recorded number of psyllids per week from five trees in a single orchard (25 yellow sticky traps) was $>2,600$ from Bhalwal region. In other surveyed regions, the captured number of psyllids ranged from 900 in Sillanwali to $\approx 500$ to 700 in Sargodha and Kotmomen (Fig. 3A to D). It should be noted that data collected from yellow sticky traps may not represent the psyllid population data accurately because other environmental factors may influence the number of insects trapped (30).

Detection of ' $\boldsymbol{C a}$. L. asiaticus' in psyllids. In total, 305 psyllid samples collected from 43 orchards of 11 citrus-growing areas (Fig. 1) from four districts of Punjab province were tested for the presence of HLB-associated ' $\mathrm{Ca}$. L. asiaticus'. These samples were analyzed by conducting 2,321 multiple psyllid extractions ( 2 to 5 psyllids/extraction) representing a total of 6,216 psyllids.

During the months of February to May, 59 of 139 psyllid samples tested (in 1,766 extractions representing 3,877 psyllids) were positive $(42 \%)$ for ' $C a$. L. asiaticus'. During summer months of June and July 2009 and 2010, 4 of 54 samples were positive (7\%) for ' $\mathrm{Ca}$. L. asiaticus'. In all, 674 psyllids were analyzed by conducting 181 extractions during this period. Analysis of the
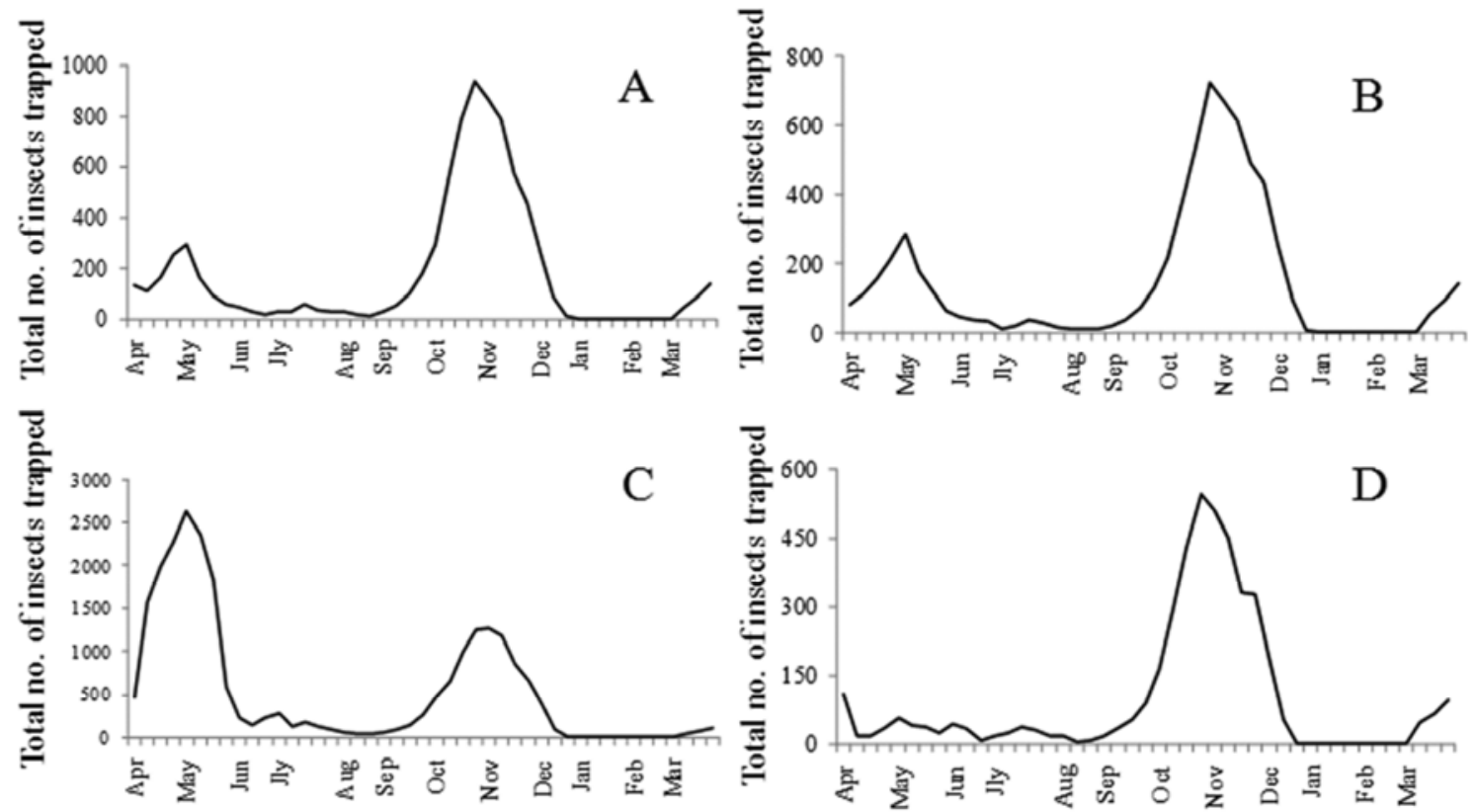

Fig. 3. Population dynamics of Diaphorina citri in four different 'Kinnow' mandarin orchards located in A, Sillanwali (region 6); B, Sargodha (region 5); C, Bhalwal (region 2); and D, Kot Momen (region 3). Total number of psyllids trapped on 25 yellow sticky traps (10 by $15 \mathrm{~cm}$ ) on five trees at each location was recorded. Weekly data for 45 weeks are shown (April 2008 to March 2009). 
autumn population peak from November 2009 showed 8 of 111 samples positive (7\%) for ' $\mathrm{Ca}$. L. asiaticus'. In total, 1,665 psyllids were tested by conducting 380 extractions. Monthly results of psyllid testing are shown in Table 1.

The percentage of ' $C a$. L. asiaticus'-positive samples varied in the different areas surveyed. We tested 106 to 1,673 psyllids from each of the 11 regions in multiple psyllid extractions. The percentage of ' $C a$. L. asiaticus'-positive samples was 9 to $50 \%$. No positive samples were found in three regions (Gojra Talwandi, Lalian, and Shahpur) from which the psyllid samples were collected only during June or November. The tests indicated widespread presence of ' $\mathrm{Ca}$. L. asiaticus'-positive psyllids in the citrus belt of Pakistan (Table 2) especially during the February to May (spring) period.

A more precise estimate of the percent positive psyllids was obtained by analysis of single psyllids. In total, 1,357 psyllids were subjected to single-psyllid extractions and tested. In total, $19 \%$ positives were obtained: $7.5 \%$ in February $(n=40), 12 \%$ in March $(n=100), 25 \%$ in April $(n=695), 13 \%$ in May $(n=496)$, and $0 \%$ in June, July, and November $(n=113)$ (Table 3$)$.

Detection of ' $\mathrm{Ca}$. $\mathbf{L}$. asiaticus' in citrus. ' $\mathrm{Ca}$. L. asiaticus' was detected in 52 plants $(n=207)$ from all areas studied (Fig. 5).
However, more positives were detected in summer $(32 \% ; n=110)$ than spring $(18 \% ; n=97)$. All four citrus varieties tested, including the two commercial varieties Mosambi and Kinnow, were found to carry ' $\mathrm{Ca}$. L. asiaticus'. We obtained $\mathrm{Ct}$ values as low as 23 (for $16 \mathrm{~S}$ region of ' $\mathrm{Ca}$. L. asiaticus' in qPCR analysis) from positive plants sampled in June to August, when very few ' $\mathrm{C} a$. L. asiaticus'-positive psyllids were found. This result indicates that, during months that are not optimal for detection of ' $\mathrm{Ca}$. L. asiaticus' from the psyllid, the bacterium is detectable from the leaf tissue.

When psyllids are used for testing, March to May (spring) may be the best times to detect HLB-associated ' $\mathrm{Ca}$. L. asiaticus'. During the hot summer months of June to July, immediately after the beginning of the monsoon rains, or during the psyllid population peak in autumn, psyllids were mostly negative for ' $C a$. L. asiaticus'. With plants, 'Ca. L. asiaticus' positives could be found in spring as well as in summer, although the relative proportions of live and dead bacteria are not known (Fig. 6; additional data not shown). During spring, we found $18 \%$ of plant samples $(n=$ 97) and $38 \%$ of psyllid samples $(n=126)$ to be ' $\mathrm{Ca}$. L. asiaticus' positive. In summer, $32 \%$ of plant samples $(n=110)$ and $0.07 \%$ of psyllid samples $(n=165)$ tested positive for ' $C a$. L. asiaticus' (Fig. 6).

A
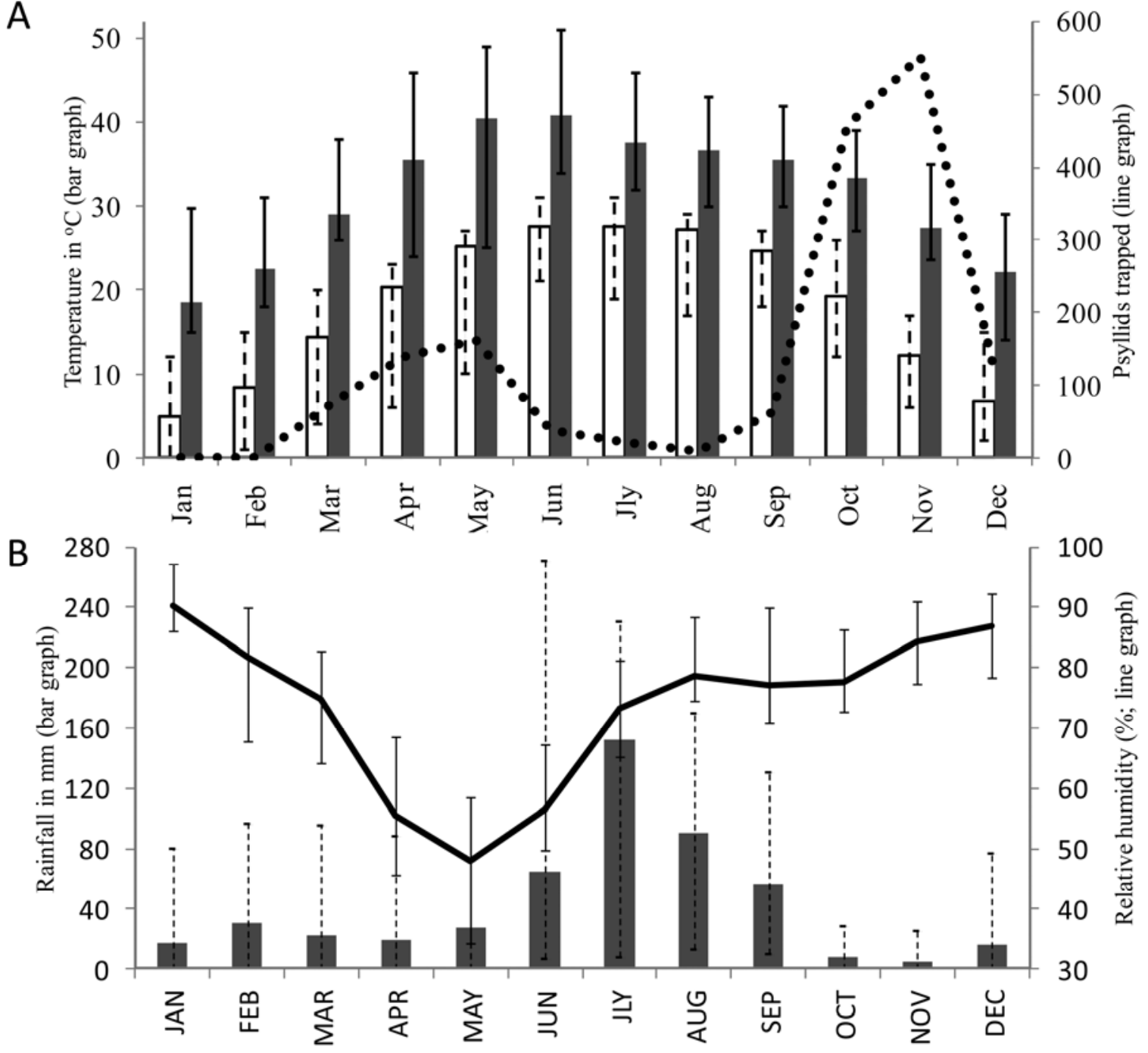

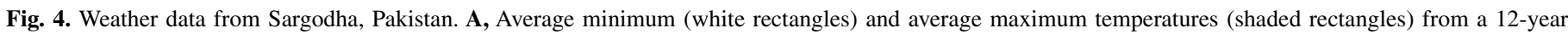

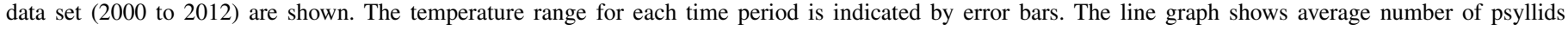

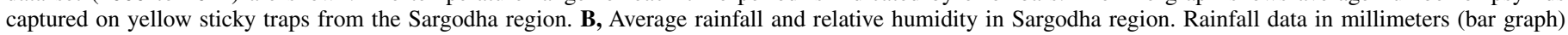

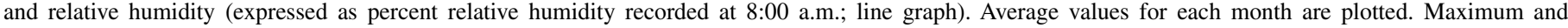

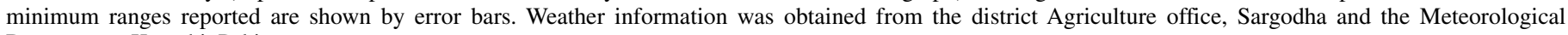
Department, Karachi, Pakistan. 
Sequencing of genomic regions of ' $\mathrm{Ca}$. L. asiaticus' isolates from Pakistan. To confirm the presence of ' $C a$. L. asiaticus' in samples by a different method in addition to qPCR, and to compare sequences of the Pakistan ' $\mathrm{Ca}$. L. asiaticus' strain with the sequence of ' $C a$. L. asiaticus' psy62 described from Florida (24), we conducted PCR amplifications of selected genomic regions. The products were cloned and sequenced, and these sequences of the Pakistan strain of ' $\mathrm{Ca}$. L. asiaticus' were aligned to the Florida strain psy62 genomic sequences. The seven genomic regions PCR amplified from $D$. citri and plant DNA obtained from various regions of Pakistan are shown in Table 4. In five of the seven regions analyzed, the sequences of Pakistan strain of ' $\mathrm{Ca}$. L. asiaticus' was 99 to $100 \%$ identical to the Florida strain. Interestingly, in two regions identified as having bacteriophage-related sequences, there was 10 to $15 \%$ sequence variability compared with ' $\mathrm{Ca}$. L. asiaticus' strain psy62 from Florida and also when compared with samples obtained from Shamsabad, Lalian, Kot Momen, and Sargodha regions of Pakistan. All unique sequences were deposited in GenBank (Table 4, GenBank accession numbers). The nucleotide alignment of the phage region that shows differences between the Pakistan isolates and the Florida strain psy62 is shown in Supplemental Figure 1.

\section{DISCUSSION}

The citrus industry in Pakistan has been hampered by citrus decline for over a century. Reports of citrus diseases similar to HLB, described as citrus dieback, date back to the 18th century (reported by Roghoji Bhonsale, cited by Capoor) (13). In a 1912 report of the insects belonging to the family Psyllidae collected from various regions of India, Crawford lists 14 psyllid genera, including D. citri (as Euphalerus citri (Kuwayama)) $(19,20,48)$. The psyllids were reported to be present in "considerable numbers" on citrus trees in 1909 (19); the diagrams published in Crawford's paper show wing morphology identical to D. citri that is now common in Florida while the male and female genitalia are slightly different from $D$. citri. Because the area described is the center of origin for the Diaphorina spp. that colonize members of the family Rutaceae $(27,37)$, there might be several closely related species (S. E. Halbert, personal communication). There were reports of serious attack of citrus trees by D. citri in 1916 in the Sargodha region of Pakistan, resulting in substantial financial

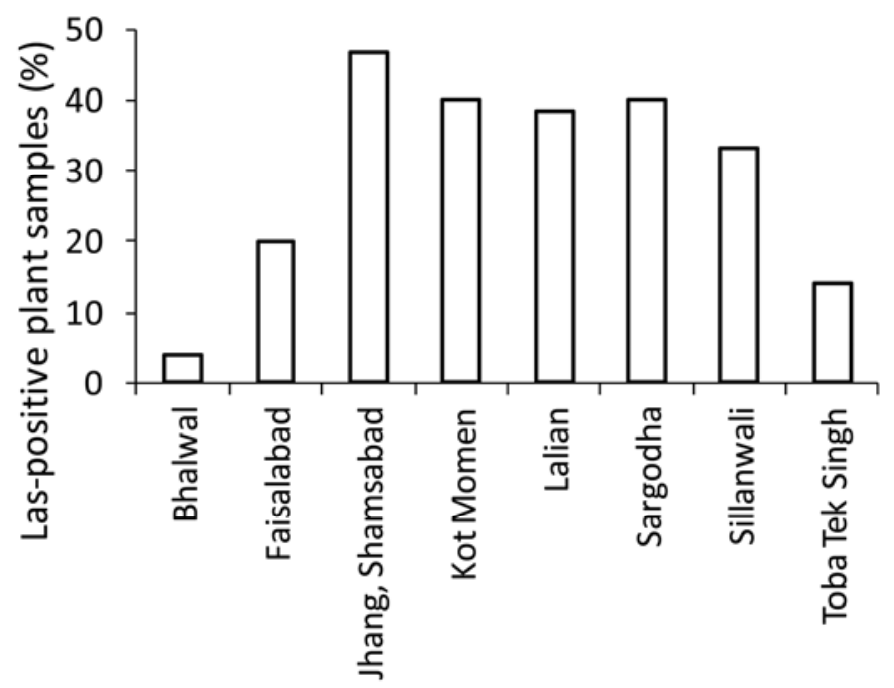

Fig. 5. Analysis of plant samples for the presence of 'Candidatus Liberibacter asiaticus'. Citrus samples were collected from eight regions in the Pakistan citrus belt are shown on $\mathrm{X}$ axis. Percent positive samples for ' $\mathrm{Ca}$. L. asiaticus' are shown on $\mathrm{Y}$ axis. Numbers of samples tested were 43 (Bhalwal), 27 (Faisalabad), 24 (Jhang, Shamsabad), 10 (Kot Momen), 44 (Lalian), 46 (Sargodha), 3 (Sillanwali), and 10 (Toba Tek Singh). losses (38). Husain and Nath (38) were the first to report damage in citrus infested with $D$. citri and described symptoms that match the HLB symptoms described today. They further hypothesized that the psyllids inject some poison to cause symptoms. Although several factors were implicated in citrus dieback (7), it appears probable that the presence of psyllids as early as 1909 (19), the citrus dieback symptoms, and the resulting loss of yield associated with it known to exist at the time and the reports of yield loss in citrus trees infested with $D$. citri $(38)$ indicate that HLB was most likely the major factor responsible for citrus decline in the Indian subcontinent for at least 100 years. It is probable that HLB associated with $D$. citri (then known as citrus dieback) was present in the Indian subcontinent before moving to China (36). Husain and Nath (38) conducted their studies in Sargodha and Faisalabad (then known as Lyallpur) and surrounding regions, where the present study was also carried out (Fig. 1).

In Pakistan, D. citri is widespread and has coexisted with citrus for over a century. The disease has been endemic in the Indian subcontinent for a long time (7). Because maximum diversity of the genus Diaphorina is known to exist in the Indian subcontinent, it is presumed to be the place of origin of the Asian citrus psyllid $(10,27,37)$. In the western hemisphere, where HLB has been introduced recently, the disease progression has been rapid. In a large citrus orchard in south Florida, the logistic rate of disease increase was estimated to be in the range of 0.002 to 0.39 in a period of 10 months (26). Active HLB mitigation efforts are not known in Pakistan. At this rate of disease spread, the citrus industry could not have survived with the psyllid and possibly with ' $C a$. L. asiaticus' for at least 100 years. Citrus is still grown commercially in many regions of the Indian subcontinent, including the Punjab area of Pakistan, indicating that the disease is not as severe as presently seen in Brazil or Florida, and that a delicate balance between the host, vector, environment, and disease may exist.

The Liberibacters associated with citrus HLB differ in their sensitivity to high temperatures (12). Many recent greenhouse and laboratory experiments conducted by scientists in Brazil and Florida indicate the temperature sensitivity of the HLB-associated psyllid and the implication is that, in very hot climates, HLB may

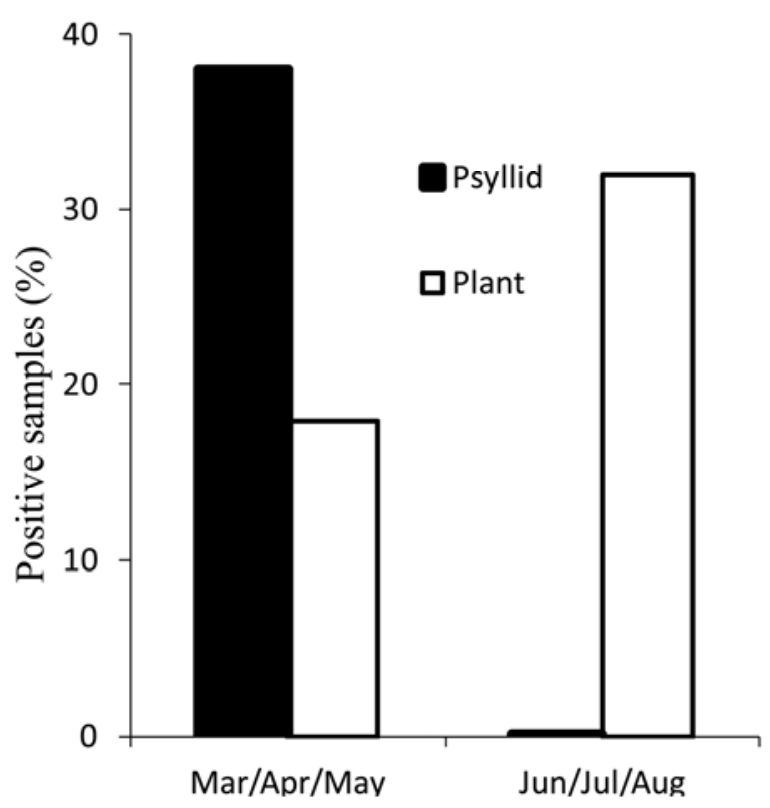

Fig. 6. Summary of testing of psyllids and citrus during spring and summer for the presence of 'Candidatus Liberibacter asiaticus'. During March to May, 126 psyllid samples (3,675 psyllids) and 97 plant samples were tested for the presence of ' $\mathrm{Ca}$. L. asiaticus'. During June to August, 165 psyllid samples (674 psyllids) and 110 plant samples were analyzed. Open bars represent psyllid positives and shaded bars represent plant positives. 
not become a serious concern. Lopes et al. (46) conducted experiments using citrus cultivars infected with ' $C a$. L. asiaticus' and ' $C a$. L. americanus' by incubating potted citrus trees in growth chambers maintained at different temperatures. ' $\mathrm{Ca}$. L. americanus' was sensitive to high temperatures and was barely detectable (titer of $10^{1}$ cells/g of leaf midrib) from infected plants incubated at $35^{\circ} \mathrm{C}$. ' $\mathrm{Ca}$. L. asiaticus' was considered "heat tolerant" because plants exposed to $35^{\circ} \mathrm{C}$ had high titers $\left(10^{7}\right.$ cells/g of leaf midrib) of the bacterium. However, when incubated at $38^{\circ} \mathrm{C}$ for $6 \mathrm{~h}$ /day over a period of 90 days, ' $\mathrm{Ca}$. L. asiaticus' titers reduced from $10^{7}$ to $\approx 10^{3}$ cells $/ g$ of leaf midrib. It was concluded that the heat-tolerant ' $\mathrm{Ca}$. L. asiaticus' can withstand up to a maximum of $35^{\circ} \mathrm{C}$ (46). In experiments conducted in Florida under greenhouse situations, Hall et al. (33) observed a linear increase in the number of eggs laid by the psyllid between 17 and $32^{\circ} \mathrm{C}$. Oviposition was significantly reduced above this temperature and, at $41^{\circ} \mathrm{C}$, the mortality of $D$. citri was very high.

The Asian citrus psyllid can survive temperatures as high as $45^{\circ} \mathrm{C}$, as observed by Aubert in Saudi Arabia (10,33). In Pakistan, the average daytime summer temperatures are 38 to $40^{\circ} \mathrm{C}$ in May to July, often reaching $45^{\circ} \mathrm{C}$ and occasionally exceeding $50^{\circ} \mathrm{C}$ (Fig. 4). Although the populations decline, the psyllid survives (Fig. 3). In the present study, the psyllid testing analysis indicated that, during relatively hot periods, the HLB-associated bacterium was not detectable in D. citri (Table 1) but the bacterium was easily detectable from plants (Fig. 6; Ct values of 23 to 32 for $16 \mathrm{~S}$ rDNA region). ' $C a$. L. asiaticus' detected from plants during hot weather may not be transmissible because the psyllids collected during both summer and the following autumn showed a very low percentage of ' $\mathrm{Ca}$. L. asiaticus' positives. In addition, the qPCR assay used does not differentiate between living and dead bacteria (57). The bacteria may also inhabit the cooler regions of the plant such as the inner canopy and roots (58).

Multiple environmental factors in Pakistan may determine the survival of both the vector and the bacterium (53). Average maximum temperatures in citrus-growing areas of California, Texas, and Arizona reach 35 to $40^{\circ} \mathrm{C}$ for $\approx 3$ months in a year (Fig. 7), often reaching $45^{\circ} \mathrm{C}$ or exceeding $50^{\circ} \mathrm{C}$ (in Arizona). Observations recorded by Lopes et al. (46) suggest that the effect of HLB on citrus plants may be relatively milder in these regions because of hot summer temperatures. However, our observations in Pakistan suggest that the effect of temperature on the vector and the bacteria is complex and may be mitigated by other environmental factors. High saturation deficits favor $D$. citri populations at temperatures $>40^{\circ} \mathrm{C}$. When relative humidity is not high and host plant leaves remain turgid, psyllids may survive due to evaporative cooling (10).

The possibility of subjecting HLB-positive citrus plants to high temperatures for thermotherapy is being investigated by several researchers (35). Although this is a promising approach to mitigate HLB in a controlled environment, the utility of such an approach for field trees may be limited. Our results show that the crop of psyllids during November (autumn) do not carry ' $\mathrm{Ca}$. L. asiaticus', probably because maximum temperatures reaching $\geq 50^{\circ} \mathrm{C}$ during the summer months are detrimental to the bacteria in the insect vector. Although we were able to detect the pathogen from mature leaves during the hot summer months, it is probable that most bacteria in the plant tissue are either dead or nontransmissible because the psyllid population in the autumn season (September to November) is mostly ' $\mathrm{Ca}$. L. asiaticus' negative (Table 1). In Florida, the highest percentage of ' $\mathrm{Ca}$. L. asiaticus'positive psyllids is usually found in October to November (47), in direct contrast to our findings in Pakistan. We hypothesize that higher summer temperatures in Pakistan may be a major factor contributing to this difference, probably resulting in either dead or nontransmissible bacteria in shoots. Natural thermotherapy may occur during hot seasons in plants but, when temperatures are favorable, bacteria in citrus roots may move to the tender flush and, as the bacterial titer builds up, the psyllids are able to reacquire the pathogen. This phenomenon may be leading to the natural mitigation of HLB under field conditions and might have contributed to the long-term survival of the citrus industry in Pakistan.

We compared the average, minimum, and maximum temperatures recorded for the citrus-growing regions of United States (over a 30-year period) with Sargodha, Pakistan (over a 12-year period) (Fig. 7). Maximum temperatures of $\geq 50^{\circ} \mathrm{C}$ is probably a major factor responsible for eliminating ' $\mathrm{Ca}$. L. asiaticus' from the psyllids and resulting in presumably dead or nontransmissible ' $C a$. L. asiaticus' in citrus plants in Pakistan. Among citrus-growing regions of the United States, such high temperatures are recorded only from Arizona. The maximum summer temperatures recorded in California are $\approx 6$ to $7{ }^{\circ} \mathrm{C}$ lower than in Pakistan and may or may not be sufficient to eliminate ' $\mathrm{Ca}$. L. asiaticus' from the psyllids. Other environmental factors in addition to temperature may have a role in the presumed thermotherapy phenomenon. Humidity and saturation deficits may also influence the microclimate and affect the body temperature of the psyllids and citrus leaves (10). All these factors may determine the ' $\mathrm{C} a$. L. asiaticus' titers in the psyllid vector and in the plant canopy after summer months.

In Pakistan, the winter temperatures during December and January (average minimum temperatures of 5 to $7^{\circ} \mathrm{C}$, with a minimum of $0^{\circ} \mathrm{C}$ ) resulted in a low population peak for the psyllid. Winter temperatures in all the citrus-growing regions of the United States are much lower than the temperatures recorded in Sargodha and may result in a population decline during winter months. During the two population peaks in April and November, the maximum temperatures in Pakistan and the citrus-growing regions of the United States are comparable (5 to $6^{\circ} \mathrm{C}$ lower in California during November). The minimum temperatures are much lower $\left(10\right.$ to $\left.12^{\circ} \mathrm{C}\right)$ in California than in Pakistan. The population peaks will also be determined by many other factors such as rainfall, presence of tender flush, humidity, and so on (9).

Psyllid population dynamics vary in different climatic situations. In our study we collected psyllids from four regions (Sillanwali, Sargodha, Bhalwal, and Kot Momen) and observed certain variations in psyllid population peaks. It appears that a population peak during April (spring) is a common occurrence in Pakistan. During April, there was a population peak in three of the four regions (not in the Kot Momen orchard). Because this was not a controlled study, efforts were not made to instruct the local citrus growers to follow any specific psyllid control procedures. We were interested in assessing the current disease status in Pakistan and obtaining information that would lead to a better understanding of the HLB situation.

The local psyllid population dynamics will vary depending on many factors, including availability of tender flush $(8,31,53)$. Presence of citrus relatives that provide tender flush throughout the year would have a positive effect of psyllid populations (58). The rainfall pattern will have an effect on the presence of tender flush and direct impact on survival of psyllid eggs and nymphs and on leaf temperatures (53). Temperature, humidity, nutritional status of the plants, presence of natural enemies, and local orchard management practices are known to influence psyllid population dynamics (53). In a 3-year study at Haryana, India, Lakra et al. (44) have identified key psyllid mortality factors such as maximum daily temperatures of $\geq 45^{\circ} \mathrm{C}$ coupled with low relative humidity $(<40 \%)$ during May to June, low minimum temperatures $\left(<5^{\circ} \mathrm{C}\right)$ during December to February, and heavy rains $(>300 \mathrm{~mm})$ during July $(44,59)$. The population dynamics of psyllids in recently invaded areas should be studied in detail and correlated with local meteorological data to plan spray schedules that reduce psyllid numbers and mitigate the disease.

We detected ' $\mathrm{Ca}$. L. asiaticus' in $\approx 22 \%$ of a total of 305 psyllid samples by qPCR using multiple psyllid extractions. Psyllids 
collected from most areas in this study were positive for ' $\mathrm{Ca}$. L. asiaticus' (Table 2), indicating the widespread occurrence of the pathogen. In two regions, Mandi Bahuddin and Lalian, very low numbers of ' $\mathrm{Ca}$. L. asiaticus'-positive psyllids were documented. At these locations, psyllids were collected during summer months when positive psyllids are known to be in low numbers (Table 1). Pathogen detection was higher in psyllid samples collected during March to May (spring) during two successive years (Table 1), compared with other seasons. Based on our data, in Pakistan, it may be advisable to do psyllid testing during March to May because many positive psyllids were found during this period. Although November is the peak period for psyllid populations, we could not detect ' $\mathrm{Ca}$. L. asiaticus' from psyllids during autumn.
Apparently the nymphs that develop into the November adult population did not acquire ' $C a$. L. asiaticus' from citrus.

In São Paulo State, Belasque et al. (11) have shown that, when active disease management efforts are not practiced, percentage of HLB affected trees increased from 2 to $\approx 16 \%$ within a single year. In many parts of Pakistan, HLB has been in existence for almost a century (38). These orchards were not aggressively treated to control the psyllid, nor were the diseased trees removed. Presumably, opportunities for disease spread and establishment are optimal. However, diseased trees are still yielding fruit, albeit at much reduced levels. The dynamics of disease development in Pakistan are different from Brazil or the United States, where ' $\mathrm{Ca}$. L. asiaticus' is a recently introduced pathogen. In Pakistan, the
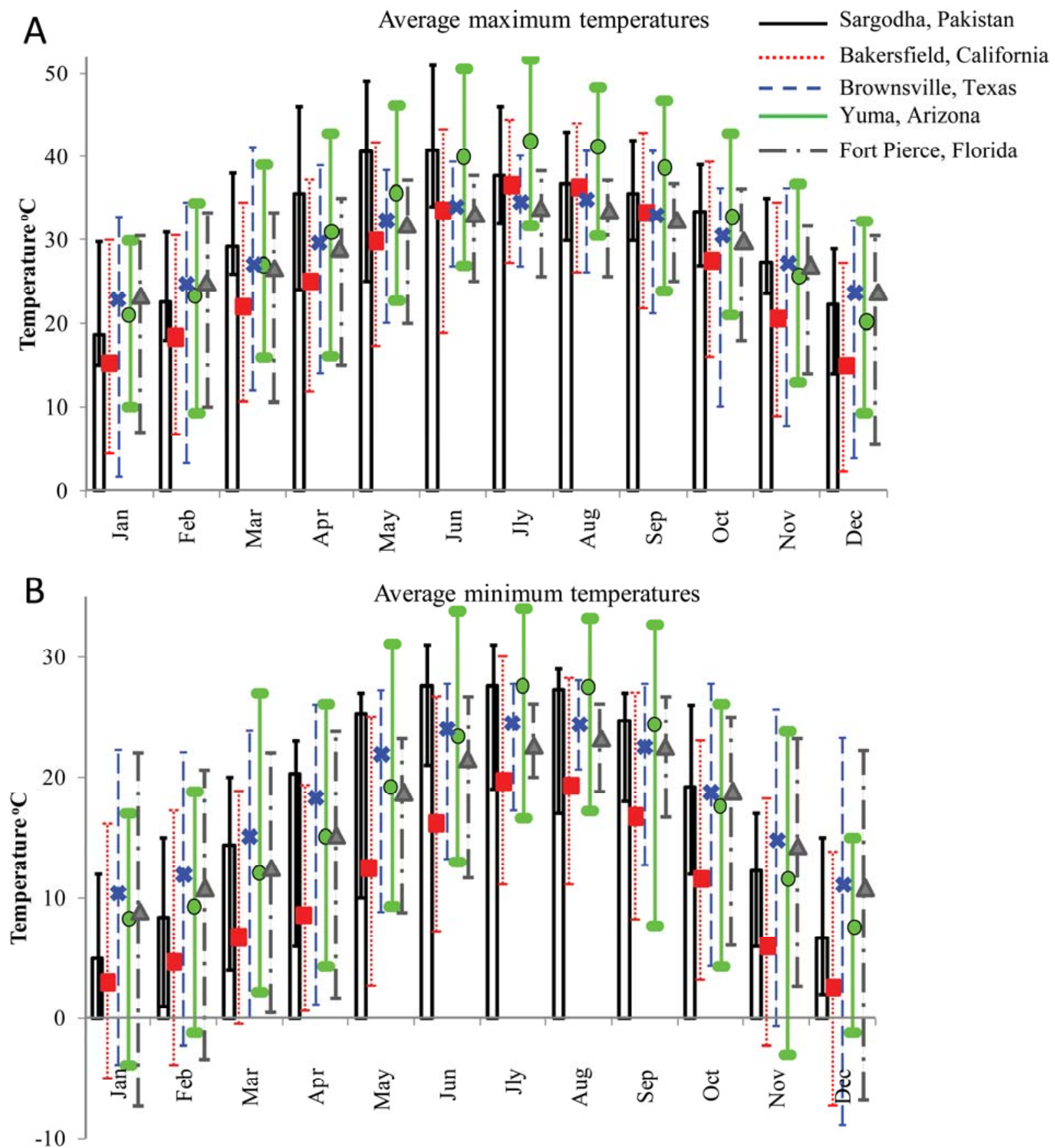

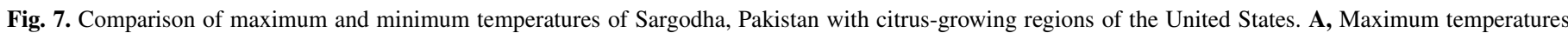

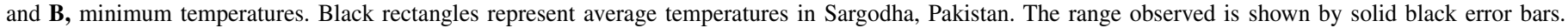

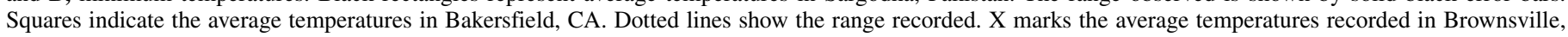

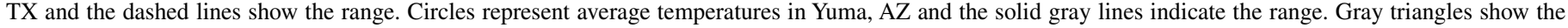

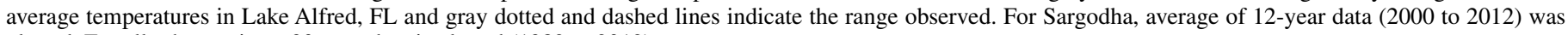
plotted. For all other regions, 30-year data is plotted (1982 to 2012). 
plant host, insect vector, and pathogen have coexisted for over a century and citrus is still commercially grown. Many factors could contribute to this scenario, including increased tolerance in citrus hosts, differences in the ' $\mathrm{Ca}$. L. asiaticus' genotypes or, most importantly, environmental factors. The absence of ' $\mathrm{Ca}$. L. asiaticus' in psyllids during autumn and, presumably, the presence of mostly dead ' $\mathrm{Ca}$. L. asiaticus' in citrus leaves after harsh summer temperatures might contribute to maintenance of a balance between the host, pathogen, and disease.

To test whether the ' $C a$. L. asiaticus' strain prevalent in Pakistan is different from the ' $C a$. L. asiaticus' strain psy62 described from Florida, we have conducted limited sequence analysis of seven genomic regions of ' $\mathrm{Ca}$. L. asiaticus' obtained from citrus plants from different regions of the Sargodha area. The sequences generated from the ' $\mathrm{Ca}$. L. asiaticus' strain from Pakistan (Table 4 ) are $\approx 99 \%$ similar to the Florida strain in five genomic regions. However, the two phage regions studied showed a significant amount of variability. Further characterization of the variable regions in the different populations of ' $\mathrm{Ca}$. L. asiaticus' may be useful in understanding the disease dynamics of the citrus-HLB pathosystem in Pakistan.

Management of HLB in Pakistan is challenging due to the absence of nursery regulations mandating use of disease-free planting material, widespread occurrence of the psyllid vector, and presence of HLB for a long period of time. The practice of plant propagation by air layering from HLB-infected trees has led to the nearly complete disappearance of sweet lime $(C$. limettioides Tan.) plantations in Pakistan. Even though HLB has been known from the Indian subcontinent for $\approx 100$ years $(26)$, there has not been a detailed study to detect and characterize the HLBassociated pathogen from Pakistan. The present study is an effort to assess the actual status of HLB in Pakistan based on sensitive detection methods and molecular characterization of ' $\mathrm{Ca}$. L. asiaticus' isolates from both the citrus plants and the insect vector, along with the analysis of vector preponderance data. An understanding of the psyllid population dynamics and the disease situation under these conditions may be of immense value to the Pakistan citrus industry. Disease mitigation is difficult in older orchards because the usual management practices may not be adequate to cope with the damage. However, planting of new citrus orchards using disease-free plants raised in protected nurseries and area-wide management of the vector should be done as is being practiced in parts of Florida, Texas, and Brazil. Establishment of facilities for molecular detection would be critical for proper identification of HLB-positive psyllids and plants. Local monitoring of the psyllid populations (Fig. 3) will be helpful in identifying critical periods when insect control is logistically feasible and financially affordable. Our study shows that $D$. citri is very well established throughout the Punjab province of Pakistan. The psyllid population is low during hot summer months (June to August) and also during cold months (January to February), and insecticide sprays during these two times may be effective in controlling psyllid populations. Additional sprays may be applied as needed. In Florida, insecticide sprays for management of psyllids are recommended during winter when the population is low (dormant sprays) (51).

HLB has not been adequately controlled anywhere in the world. It is an invasive disease that is known to spread rapidly in new areas and cause immense crop losses. However, in Pakistan, the pathogen, its insect host, and the plant host have coexisted for a very long time (38). Although damage is evident and the yield of citrus much lower compared with other citrus-growing regions of the world, continued presence of the pathogen and the vector have not completely destroyed the citrus industry. Further studies of this pathosystem in Pakistan would be useful in developing management techniques in places with similar climatic conditions such as California and Texas in the United States, where HLB has been recently introduced.

\section{ACKNOWLEDGMENTS}

This research was made possible by support from the Pakistan-U.S. Science and Technology Cooperation Program, California Citrus Research Board, and the Higher Education Commission of Pakistan. We thank L. Heldoorn and E. Rodriguez for excellent technical help; E. Iqbal, University of Agriculture, Faisalabad, for laboratory support for DNA extractions in Faisalabad, Pakistan; and S. E. Halbert for providing expert advice in proper identification of psyllid diagrams reported from India in a 1912 publication.

\section{LITERATURE CITED}

1. Abbas, M., Khan, M. M., Mughal, S. M., and Khan, I. A. 2005. Prospects of classical cross protection technique against Citrus tristeza closterovirus in Pakistan. Hortic. Sci. (Prague) 32(2):74-83.

2. Ahmad, R. 1961. Citrus psylla: its damage, population and efficacy of some insecticides against it. Pak. J. Sci. 13:195-200.

3. Akhtar, M.A., and Ahmad, I. 1999. Incidence of citrus greening disease in Pakistan. Pak. J. Phytopathol. 11:1-5.

4. Albrecht, U., and Bowman, K. 2011. Tolerance of the trifoliate citrus hybrid US-897 (Citrus reticulata Blanco $\times$ Poncirus trifoliata L. Raf.) to huanglongbing. HortScience 46:16-22.

5. Altaf, N., and Khan, A. R. 2008. Variation within Kinnow (Citrus reticulata) and rough lemon (Citrus jambheri). Pak. J. Bot. 40:589-598.

6. Anonymous, 2010. Page 89 in: Agricultural Statistics of Pakistan (2008-09). http://www.pbs.gov.pk/content/agricultural-statistics-pakistan-2010-11

7. Asana, R. D. 1958. The citrus die-back problem in relation to cultivation of citrus fruits in India. Indian J. Hortic. 15:283-286.

8. Atwal, A. S., Chaudhary, J. P., and Ramzan, M. 1970. Studies on the development and field population of citrus psylla, Diaphorina citri Kuwayama (Psyllidae: Homoptera). J. Res. Punjab Agric. Univ. 7:333338.

9. Aubert, B. 1987. Trioza erytreae Del Guercio and Diaphorina citri Kuwayama (Homoptera: Psylloidea), the two vectors of citrus greening disease: biological aspects and possible control strategies. Fruits 42:149162.

10. Aurambout, J. P., Finlay, K. J., Luck, J., and Beattie, G. A. C. 2009. A concept model to estimate the potential distribution of the Asiatic citrus psyllid (Diaphorina citri Kuwayama) in Australia under climate changea means for assessing biosecurity risk. Ecol. Model. 220:2512-2524.

11. Belasque, J., Jr., Bassanezi, R. B., Yamamoto, P. T., Ayres, A. J., Tachibana, A., Violante, A. R., Tank, J., Jr., Di Giorgi, F., Tersi, F. E. A., Menezes, G. M., Dragone, J., Jank, R. H., Jr., and Bové, J. M. 2010. Lessons from huanglongbing management in São Paulo State, Brazil. J. Plant Pathol. 92:285-302.

12. Bové, J. M. 2006. Huanglongbing: a destructive, newly-emerging, century-old disease of citrus. J. Plant Pathol. 88:7-37.

13. Capoor, S. P. 1963. Decline of citrus trees in India. Bull. Natl. Inst. Sci. India 24:48-64.

14. Capoor, S. P., Rao, D. G., and Viswanath, S. M. 1967. Diaphorina citri Kuway., a vector of the greening disease of citrus in India. Indian J. Agric. Sci. 37:572-576

15. Cen, Y., Zhang, L., Xia, Y., Guo, J., Deng, X., Zhou, W., Sequeira, R., Gao, J., Wang, Z., Yue, J., and Gao, Y. 2012. Detection of 'Candidatus Liberibacter asiaticus' in Cacopsylla (Psylla) citrisuga (Hemiptera: Psyllidae). Fla. Entomol. 95:304-311.

16. Chen, J., Deng, X., Civerolo, E. L., Lee, R. F., Jones, J. B., Zhou, C., Hartung, J. S., Manjunath, K. L., and Brlansky, R H. 2011. "Candidatus Liberibacter species": without Koch's postulates completed, can the bacterium be considered as the causal agent of citrus huanglongbing (yellow shoot disease)? Acta Phytopathol. Sin. 41:113-117.

17. Chohan, S. N., Qamar, R., Sadiq, I., Azam, M. Holford, P., and Beattie, A. 2007. Molecular evidence for the presence of Huanglongbing in Pakistan. Australas. Plant Dis. 2:37-38.

18. Coletta-Filho, H. D., Targon, M. L. P. N., Takita, M. A., De Negri, J. D., Pompeu, J., Jr., Machado, M. A., do Amaral, A. M., and Muller, G. W. 2004. First report of the causal agent of huanglongbing ("Candidatus Liberibacter asiaticus") in Brazil. Plant Dis. 88:1382.

19. Crawford, D. L. 1912. Indian Psyllidae. Records Indian Museum 7:419435.

20. Crawford, D. L. 1919. The jumping plant lice of the Palaeotropics and the South Pacific Islands. Philipp. J. Sci. 15:139-207.

21. Da Graça, J. V., and Korsten, L. 2004. Citrus huanglongbing: review, present status and future strategies. Pages 229-245 in: Diseases of Fruits and Vegetables. S. A. M. H. Naqvi, ed. Kluwer Academic Publishers, Dordrecht, The Netherlands.

22. Donovan, N. J., Beattie, G. A. C., Chambers, G. A., Holford, P., Englezou, A., Hardy, S., Dorjee, Wangi, P, Thinlay, and Om, N. 2011. First report of 
'Candidatus Liberibacter asiaticus' in Diaphorina communis. Australas. Plant Dis. 7:1-4.

23. Doyle, J. J., and Doyle, J. L. 1990. Isolation of plant DNA from fresh tissue. Focus 12:13-15.

24. Duan, Y. P., Zhou, L. J., Hall, D. G., Li, W. B., Doddapaneni, H., Lin, H., Liu, L., Vahling, C. M., Gabriel, D. W., Williams, K. P., Dickerman, A., Sun, Y. and Gottwald, T. 2009. Complete genome sequence of citrus huanglongbing bacterium, "Candidatus Liberibacter asiaticus" obtained through metagenomics. Mol. Plant-Microbe Interact. 22:1011-1020.

25. Fraser, L. R., and Singh, D. 1966. Greening virus, a threat to citrus industry. Indian Hortic. 10:21-22

26. Gottwald, T. R. 2010. Current epidemiological understanding of citrus huanglongbing. Annu. Rev. Phytopathol. 48:119-139.

27. Halbert, S. E., and Manjunath, K. L. 2004. Asian citrus psyllids (Sternorrhyncha: Psyllidae) and greening disease of citrus: a literature review and assessment of risk in Florida. Fla. Entomol. 87:330-353.

28. Halbert, S. E., Manjunath, K., Ramadugu, C., and Lee, R. F. 2012. Incidence of Huanglongbing-associated 'Candidatus Liberibacter asiaticus' in Diaphorina citri (Hemiptera: Psyllidae) collected from plants for sale in Florida. Fla. Entomol. 95:617-624.

29. Halbert, S. E., and Nunez, C. A. 2004. Distribution of the Asian citrus psyllid, Diaphorina citri Kuwayama (Rhynchota: Psyllidae) in the Caribbean basin. Fla. Entomol. 87:401-402.

30. Hall, D. G. 2009. An assessment of yellow sticky card traps as indicators of the abundance of adult Diaphorina citri (Hemiptera:Psyllidae) in citrus. J. Econ. Entomol. 102:446-452.

31. Hall, D. G., and Albrigo, L. G. 2007. Estimating the relative abundance of flush shoots in citrus with implications on monitoring insects associated with flush. HortScience 42:364-368.

32. Hall, D. G., Hentz, M. G., and Adair, R. C. 2008. Population ecology and phenology of Diaphorina citri (Hemiptera: Psyllidae) in two Florida citrus groves. Environ. Entomol. 37:914-924.

33. Hall, D. G., Wenninger, E. J., and Hentz, M. G. 2011. Temperature studies with the Asian citrus psyllid, Diaphorina citri: cold hardiness and temperature thresholds for oviposition. J. Insect Sci. 11:83.

34. Hoddle, M. S. 2012. Foreign exploration for natural enemies of Asian citrus psyllid, Diaphorina citri (Hemiptera: Psyllidae), in the Punjab of Pakistan for use in a classical biological control program in California, USA. Pak. Entomol. 34:1-5.

35. Hoffman, M. T., Doud, M. S., Williams, L., Zhang, M.-Q, Ding, F., Stover, E., Hall, D., Zhang, S., Jones, L., Gooch, M., Fleites, L, Dixon, W., Gabriel, D., and Duan, Y.-P. 2013. Heat treatment eliminates 'Candidatus Liberibacter asiaticus' from infected citrus trees under controlled conditions. Phytopathology 103:15-22.

36. Hoffman, W. E. 1933. Diaphorina citri Kuw. (Homoptera: Chermidae), a citrus pest in Kwangtung. Lingnan Sci. J. 15:127-132.

37. Hollis, D. 1987. A new citrus-feeding psyllid from the Comoro Islands, with a review of the Diaphorina amoena species group (Homoptera). Syst. Entomol. 12:47-61.

38. Husain, M. A., and Nath, D. 1927. The citrus psylla (Diaphorina citri, Kuw.) [Psyllidae: Homoptera]. Mem. Dep. Agric. India Entomol. Ser. 10:5-27.

39. Jagoueix, S., Bové, J. M., and Garnier, M. 1994. The phloem-limited bacterium of greening disease of citrus is a member of the alpha subdivision of the proteobacteria. Int. J. Syst. Bacteriol. 44:397-386.

40. Jagoueix, S., Bové, J. M., and Garnier, M. 1996. PCR detection of the two 'Candidatus' Liberobacter species associated with greening disease of citrus. Mol. Cell. Probes 10:43-50.

41. Khalil, S. A., Sattar, A., and Zamir, R. 2011. Development of sparseseeded mutant Kinnow (Citrus reticulata Blanco) through budwood irradiation. Afr. J. Biotechnol. 10:14562-14565.

42. Kumagai, L. B., LeVesque, C. S., Blomquist, C. L., Madishetty, K., Guo, Y., Woods, P. W., Rooney-Latham, S., Rascoe, J., Gallindo, T., Schnabel,
D., and Polek, M. 2013. First report of 'Candidatus Liberibacter asiaticus' Associated with citrus huanglongbing in California. Plant Dis. 97:283.

43. Kunta, M., Sétamou, M., Skaria, M., Rascoe, J., Li, W., Nakhla, M. K., and da Graça, J. V. 2012. First report of citrus huanglongbing in Texas. Phytopathology 102:S4.66.

44. Lakra, R. K., Singh, Z., and Kharub, W. S. 1983. Population dynamics of citrus psylla, Diaphorina citri Kuwayama in Haryana. Indian J. Entomol. 45:301-310.

45. Li, W., Hartung, J. S., and Levy, L. 2006. Quantitative real-time PCR for detection and identification of 'Candidatus Liberibacter species' associated with citrus huanglongbing. J. Microbiol. Methods 66:104-115.

46. Lopes, S. A., Frare, G. F., Bertolini, E., Cambra, M., Fernandes, N. G. Ayres, A. J., Marin, D. R., and Bové, J. M. 2009. Liberibacters associated with citrus huanglongbing in Brazil: 'Candidatus Liberibacter asiaticus' is heat tolerant, 'Candidatus L. americanus' is heat sensitive. Plant Dis. 93:257-262.

47. Manjunath, K. L., Halbert, S. E., Ramadugu, C., Webb, S., and Lee, R. F. 2008. Detection of 'Candidatus Liberibacter asiaticus' in Diaphorina citri and its importance in the management of citrus huanglongbing in Florida. Phytopathology 98:387-396.

48. Mathur, R. N. 1975. Psyllidae of the Indian subcontinent. Indian Council of Agricultural Research, New Delhi, India.

49. McClean, A. P. D., and Oberholzer, P. C. J. 1965. Citrus psylla, a vector of the greening disease of sweet orange. S. Afr. J. Agric. Sci. 8:297-298.

50. Nicholas, K. B., Nicholas H. B. Jr., and Deerfield, D. W., II. 1997. GeneDoc: analysis and visualization of genetic variation. EMBNEW.NEWS 4:14.

51. Qureshi, J. A., and Stansly, P. A. 2010. Dormant season foliar sprays of broad-spectrum insecticides: An effective component of integrated management for Diaphorina citri (Hemiptera: Psyllidae) in citrus orchards. Crop Prot. 29:860-866.

52. Shen, W., Halbert, S. E., Dickstein, E., Manjunath, K. L., Shimwela, M. M., and van Bruggen, A. H. C., 2013. Occurrence and in-grove distribution of citrus huanglongbing in North Central Florida. J. Plant Pathol. 95:359-369.

53. Teck, S. L. C., Fatimah, A., Beattie, A., Heng, R. K. J., and King, W. S. 2011. Seasonal population dynamics of the Asian Citrus Psyllid, Diaphorina citri Kuwayama in Sarawak. Am. J. Agric. Biol. Sci. 6:527535 .

54. Texeira, D. C., Ayres, J., Kitajima, E. W., Danet, L., Jagoueix-Eveillard, S., Saillard, C., and Bové, J. M. 2005. First report of a Huanglongbinglike disease of citrus in São Paulo state, Brazil and association of a new Liberibacter species, "Candidatus Liberibacter americanus", with the disease. Plant Dis. 89:107-111.

55. Thompson, J. D., Higgins, D. G., and Gibson, T. J. 1994. CLUSTAL W: improving the sensitivity of progressive multiple sequence alignment through sequence weighting, position-specific gap penalties and weight matrix choice. Nucleic Acids Res. 22:4673-4680.

56. Tomimura, K., Miyata, S., Furuya, N., Kubota, K., Okuda, M. Subandiyah, S., Hung, T.-H., Su, H.-J., and Iwanami, T. 2009. Evaluation of genetic diversity among 'Candidatus Liberibacter asiaticus' isolates collected in Southeast Asia. Phytopathology 99:1062-1069.

57. Trivedi, P., Sagaram, U. S., Kim, J. S., Brlansky, R. H., Rogers, M. E., Stelinski, L. L., Oswalt, C., and Wang, N. 2009. Quantification of viable 'Candidatus Liberibacter asiaticus' in hosts using quantitative PCR with the aid of ethidium monoazide (EMA). Eur. J. Plant Pathol. 124:553-563.

58. Tsai, J. H., Wang, J. J., and Liu, Y. H. 2002. Seasonal abundance of the Asian citrus psyllid, Diaphorina citri (Homoptera: Psyllidae) in Southern Florida. Fla. Entomol. 85:446-451.

59. Viraktamath, C. A., and Bhumannavar, B. S. 2001. Biology, ecology and management of Diaphorina citri Kuwayama (Hemiptera: Psyllidae). Pest Manage. Hortic. Ecosyst. 7:1-27. 